\title{
Evidence for genetic linkage between the ure and trh genes in Vibrio parahaemolyticus
}

\author{
TETSUYA IIDA*, ORASA SUTHIENKUL* $\ddagger$, KWON-SAM PARK*, GUANG-QING TANG*, RYOHEI K. \\ YAMAMOTO*, MASANORI ISHIBASHI†, KOICHIRO YAMAMOTO* and TAKESHI HONDA* \\ *Department of Bacterial Infections, Research Institute for Microbial Diseases, Osaka University, Osaka 565 \\ and +Department of Food Microbiology, Osaka Prefectural Institute of Public Health, Osaka 537, Japan
}

\begin{abstract}
Although $V$. parahaemolyticus does not generally produce urease, several studies have reported urease-positive $V$. parahaemolyticus isolates from clinical sources. Recently, studies have shown a complete coincidence between the urease-producing phenotype of V. parahaemolyticus strains and the possession of the thermostable direct haemolysin (TDH)-related haemolysin (TRH) gene (trh). TRH, like TDH, is considered to be an important virulence factor in the pathogenesis of $\boldsymbol{V}$. parahaemolyticus gastroenteritis. The present study attempted to identify the gene ure encoding urease in $\boldsymbol{V}$. parahaemolyticus to clarify the relationship between urease production and possession of trh. The polymerase chain reaction with mixed oligonucleotide primers targeted for conserved sequences of reported ure genes from other species was used to prepare a DNA probe to detect the $V$. parahaemolyticus ure gene. Colony hybridisation with this ure probe demonstrated that all the ure-positive strains produced urease. Considering the coincidence between production of urease and possession of $t r h$ in $V$. parahaemolyticus, it was concluded that the presence or absence of the ure gene is completely coincident with that of the trh gene in $V$. parahaemolyticus strains. Furthermore, the relative location of ure and trh on $V$. parahaemolyticus chromosomal DNA was analysed by pulsed-field gel electrophoresis. The results showed that, in all the strains examined, ure and $t r h$ were detected on the same NotI fragment, showing that the two genes localise within a relatively small portion of the chromosome DNA. These results suggest that the ure and trh genes are genetically linked in $\boldsymbol{V}$. parahaemolyticus strains.
\end{abstract}

\section{Introduction}

Vibrio parahaemolyticus is an important bacterial pathogen in food-poisoning and traveller's diarrhoea, especially in association with the eating of raw or partially cooked seafood [1]. Almost all the strains isolated from clinical sources were haemolytic on Wagatsuma's agar (a special blood agar), while only a small number of environmental isolates showed haemolysis on this medium [2]. Thus, this haemolysis, known as the Kanagawa phenomenon (KP), is considered a useful marker of virulent $V$. parahaemolyticus strains. The haemolysin responsible for the phenomenon was identified and referred to as the thermostable direct haemolysin (TDH) [1]. Recently, some clinical isolates of KP-negative V. parahaemolyticus were found

Received 24 Oct. 1996; accepted 4 Dec. 1996.

Corresponding author: Dr T. Iida.

$\ddagger$ Present address: Department of Microbiology, Faculty of Public Health, Mahidol University, Rajvithi Road, Bangkok 10400, Thailand. to produce a haemolysin referred to as the TDH-related haemolysin (TRH), which is physicochemically, immunologically and biologically similar to TDH [3, 4]. TRH-producing $V$. parahaemolyticus has been reported to cause gastroenteritis like TDH-producing isolates $[5,6]$. TDH and TRH, encoded by the $t d h$ and trh genes, respectively, are now considered to be important virulence factors in the pathogenesis of $V$. parahaemolyticus [1].

Like other vibrios, $V$. parahaemolyticus does not generally produce urease. However, several studies have reported urease-positive $V$ parahaemolyticus isolates from clinical sources, and implicated these strains in human gastroenteritis [7-18].

A recent study examined 489 clinical strains of $V$. parahaemolyticus isolated in Thailand, $8 \%$ of which were urease positive [17]. Interestingly, the ureaseproducing phenotype completely coincided with the possession of the trh gene in these strains. The finding suggested that the production of urease could be 
considered an indication of virulent (trh-possessing) $\mathrm{V}$. parahaemolyticus strains in clinical diagnosis [17]. As urease production for strains was not examined by genotype but by phenotype in the previous study [17], the genetic relationship between the production of urease and the possession of the trh gene among $V$. parahaemolyticus strains was unclear.

Thus far, neither isolation of urease nor cloning of the gene encoding urease (ure) have been reported from $V$. parahaemolyticus. The present study attempted to detect the ure gene in $V$. parahaemolyticus strains, to clarify the relationship between the urease-positive phenotype and possession of the trh gene in $V$. parahaemolyticus strains. A probe for the detection of the gene was prepared, and the distribution of the ure gene among the clinical $V$. parahaemolyticus isolates was examined; its relationship to the production of urease by the strains was then analysed. The relative location of the ure and the trh genes on the chromosomal DNA of $V$. parahaemolyticus was also determined.

\section{Materials and methods}

\section{V. parahaemolyticus strains}

One hundred and forty-seven strains of $V$. parahaemolyticus isolated from diarrhoeal patients in Thailand and 10 environmental isolates from the same country were used. The presence or the absence of $t d h$ and $t r h$ had been determined previously by the polymerase chain reaction (PCR) and the urease phenotype had been examined [17, unpublished data]. Of the 147 clinical strains, 100 strains were $t d h^{+} t r h^{-}$and urease negative, 10 strains were $t d h^{-} t r h^{-}$and urease negative, 27 strains were $t d h^{+} t r h^{+}$and urease positive, and 10 were $t d h^{-} t r h^{+}$and urease positive. The 100 $t d h^{+} t_{r h}^{-}$strains and $10 \mathrm{tdh}^{-} \mathrm{trh}^{-}$strains were randomly selected from a total of $396 \mathrm{tdh}^{+} \mathrm{trh} \mathrm{h}^{-}$and $56 \mathrm{tdh}^{-} \mathrm{trh}^{-}$strains in the original population [17]. The 10 environmental strains were isolated from seafood samples from local markets in Bangkok in 1992. All the environmental strains were $t d h^{-} t r h^{-}$and urease negative. $V$. parahaemolyticus AQ4023 [19], T4750 [20] and Escherichia coli HB101 [21] were described previously.

\section{Synthetic oligonucleotide primers for the} detection of the $V$. parahaemolyticus ure gene

Two mixed oligonucleotide primers [URE2: 5'CGTCGAATTC(A/T)(A/G)AT(A/T)(G/C)TIACIGC(T/C) G(G/C)IGGIATIGAT-3' and URE4: 5'-GCTCGAATTCA(G/A)(G/A)T(G/T)(G/A)TG(G/A)CAIACCATIAIC AT(G/A)TC-3'] were designed for PCR to detect the $V$. parahaemolyticus ure gene based on the conserved regions of the reported structural gene sequences of ureases from various bacterial and plant sources stocked in Genbank. Oligonucleotide primers were synthesised with a DNA synthesizer, Model 381A (Applied Biosystems).

\section{Preparation of template DNA for PCR}

$V$. parahaemolyticus strains were cultured in $1.5 \mathrm{ml}$ of Luria-Bertani (LB: tryptone $1 \%$, yeast extract $0.5 \%$ ) broth with $\mathrm{NaCl} 3 \%$ and incubated at $37^{\circ} \mathrm{C}$ overnight with shaking. The cell pellet was harvested by centrifugation at $8000 \mathrm{~g}$ for $2 \mathrm{~min}$. The supernate was aspirated and the cell pellet was resuspended in $500 \mu \mathrm{l}$ of distilled water. After boiling at $100^{\circ} \mathrm{C}$ for $5 \mathrm{~min}$, the suspension was centrifuged at $8000 \mathrm{~g}$ for $5 \mathrm{~min}$. The supernate, containing the bacterial DNA for use as template in $\mathrm{PCR}$, was kept at $-20^{\circ} \mathrm{C}$ before being assayed.

\section{$P C R$ conditions}

The PCR was conducted in a reaction mixture containing $10 \mathrm{mM}$ Tris- $\mathrm{HCl}(\mathrm{pH} 8.9), 80 \mathrm{mM} \mathrm{KCl}$, $1.5 \mathrm{mM} \mathrm{MgCl}_{2}$, bovine serum albumin $0.5 \mathrm{mg} / \mathrm{ml}$, $0.2 \mathrm{mM} \mathrm{dNTP}$ and $0.2 \mu \mathrm{M}$ of each primer. The total volume of the PCR mixture was $50 \mu 1$, including $10 \mu \mathrm{l}$ of template DNA solution prepared as described above and 1 unit of $T$ th DNA polymerase (Toyobo). A temperature cycle of $94^{\circ} \mathrm{C}$ for $2 \mathrm{~min}, 45^{\circ} \mathrm{C}$ for $3 \mathrm{~min}$ and $55^{\circ} \mathrm{C}$ for $3 \mathrm{~min}$ was repeated 35 times. After the reactions, the presence or the absence of amplified DNA fragments was examined by electrophoresis on agarose $0.8 \%$ gel followed by ethidium bromide staining.

\section{General molecular genetic methods}

General molecular genetic techniques such as DNA digestion with restriction endonucleases, ligation, electrophoresis and transformation were performed as described previously [21].

\section{Nucleotide sequence determination}

Nucleotide sequences were determined on a DNA sequencer Model 373A (Applied Biosystems) after sequencing reaction with PRISM Dye Primer Cycle Sequencing Ready Reaction Kit (Perkin-Elmer).

\section{Preparation of digoxigenin-labelled probes}

The 334-bp EcoRI fragment from pKY298 [19] for the trh probe and the 601-bp EcoRI fragment from pTI301 (see below) for the ure probe were labelled with digoxigenin-11-dUTP by a random primer extension method provided by a DNA labelling and detection kit (Boehringer Mannheim). Labelling procedures were according to the manufacturer's protocol. The labelled DNA fragments were separated from unincorporated nucleotides by ethanol precipitation and redissolved in TE buffer (10 mM Tris-HCl, $1 \mathrm{mM}$ EDTA, pH 8.0), then stored at $-20^{\circ} \mathrm{C}$ until use. 


\section{Colony hybridisation for the ure gene}

$V$ parahaemolyticus strains were cultured on marine agar (Difco) with $\mathrm{NaCl} 3 \%$. After incubation overnight at $37^{\circ} \mathrm{C}$, bacterial cultures from single colonies were spotted with sterilised toothpicks on to a nylon membrane (GeneScreen Plus, Dupont). V. parahaemolyticus strain AQ4023 was used as a positive control strain and $V$. parahaemolyticus T4750 was used as a negative control strain for urease production. Bacterial immobilisation and denaturation on the membrane were as described previously [21]. The membrane-bound material was hybridised with the digoxigenin-labelled ure probe in hybridisation solution containing $5 \times$ SSPE $\left(1 \times\right.$ SSPE is $0.25 \mathrm{M} \mathrm{NaCl}, 0.01 \mathrm{M} \mathrm{NaH}_{2} \mathrm{PO}_{4}$, and $1 \mathrm{mM}$ EDTA, pH 7.4), formamide $50 \%$, sodiumlaurylsarcosine (SLS) $0.1 \%$, sodium dodecyl sulphate (SDS) $0.02 \%$, denatured single-stranded salmon sperm DNA $0.1 \mathrm{mg} / \mathrm{ml}$, and blocking reagent from a DIG DNA labelling and detection kit (Boehringer Mannheim) $1 \%$. The hybridisation temperature for the ure probe was $37^{\circ} \mathrm{C}$. Immunological detection of DNA fragments hybridised with the probes was performed with anti-digoxigenin antibody conjugated with alkaline phosphatase (Boehringer Mannheim). The DNA targets were then detected with a chemiluminescent substrate for alkaline phosphatase, CSPD (Tropix), as recommended by the kit manufacturer.

\section{Extraction of bacterial DNA for conventional Southern assay}

The genomic DNA of $V$ parahaemolyticus strains was extracted from overnight cultures in LB broth with $\mathrm{NaCl} 3 \%$ following the method of Wilson [22]. Nucleic acids were precipitated with ethanol, then dissolved in TE buffer. Total genomic DNA was then digested with HindIII (Toyobo) overnight at $37^{\circ} \mathrm{C}$ for Southern analysis. The HindIII digests of bacterial genomic DNA were separated by electrophoresis on an agarose $1 \%$ gel.

\section{Pulsed-field gel electrophoresis (PFGE)}

Samples for PFGE were prepared as described previously [23] with modification. Briefly, bacterial cells were grown overnight with shaking at $37^{\circ} \mathrm{C}$ in $\mathrm{LB}$ broth containing $\mathrm{NaCl} 3 \%$. Cells were then centrifuged, resuspended with $10 \mathrm{mM}$ Tris- $\mathrm{HCl}(\mathrm{pH} 8.0), 1 \mathrm{M} \mathrm{NaCl}$, $50 \mathrm{mM}$ EDTA and mixed with an equal volume of molten low-melting-point 1.6\% agarose (LMP Agarose; Life Technologies). Agarose blocks were incubated for $2 \mathrm{~h}$ at $37^{\circ} \mathrm{C}$ in lysozyme solution (lysozyme $1 \mathrm{mg} / \mathrm{ml}$ in $10 \mathrm{~mm}$ Tris-HCl, (pH 8.0), $1 \mathrm{M} \mathrm{NaCl}, 100 \mathrm{mM}$ EDTAsodium deoxycholate $0.2 \%$, SLS $0.5 \%$, RNAase $2 \mu \mathrm{g} /$ $\mathrm{ml}$ ) and then deproteinated in proteinase $\mathrm{K} 1 \mathrm{mg} / \mathrm{ml}$ in $0.5 \mathrm{M}$ EDTA (pH 8.0), SLS $1 \%$ at $50^{\circ} \mathrm{C}$ overnight. Cell debris and proteinase $\mathrm{K}$ were then removed by four washes in $20 \mathrm{mM}$ Tris- $\mathrm{HCl}$ ( $\mathrm{pH} 8.0$ ), $50 \mathrm{mM}$ EDTA for $2 \mathrm{~h}$ each at room temperature, of which the second wash was with $1 \mathrm{mM}$ phenylmethylsulphonyl fluoride
(Sigma). The $V$. parahaemolyticus DNA in agarose blocks was digested with the restriction enzyme NotI (Toyobo). The restriction DNA fragments were resolved by PFGE in agarose 1\% gel (Molecular Biology Certified Agarose, BioRad) on a CHEF DR III System (BioRad). Before Southern transfer, the DNA fragments in the agarose were nicked by exposing the gel to ultraviolet light (UV) in a UV chamber (GS Gene Linker, BioRad).

\section{Southern hybridisation}

After electrophoresis, the DNA fragments were transferred on to a nylon membrane (GeneScreen, Dupont) with $6 \times$ SSPE as described previously [21], then hybridised with the digoxigenin-labelled trh or ure probe as described above. The hybridisation temperature for the trh probe was $30^{\circ} \mathrm{C}$ [24] and the temperature for the ure probe was $37^{\circ} \mathrm{C}$.

\section{Results}

Amplification of the V. parahaemolyticus ure gene by PCR

To detect the V. parahaemolyticus ure gene, a pair of mixed oligonucleotide primers for PCR (URE2 and URE4) were designed and synthesised, based on the nucleotide sequences of the conserved regions in the ure genes from the various bacterial and plant sources that have so far been reported. When the PCR was performed with the above two primers, a single DNA fragment of the expected size (615 bp) was amplified in the case of a urease-positive $V$. parahaemolyticus strain AQ4023, while no band was apparent in the case of a urease-negative strain, T4750 (Fig. 1). As both primers were designed to have an EcoRI site near the $5^{\prime}$ termini, the amplified DNA fragment was digested with $E c o$ RI, then ligated to the EcoRI site of a plasmid vector pUC119, resulting in the recombinant plasmid pTI301. DNA sequencing of the insert and homology searching in the DNA database, GenBank, revealed that the nucleotide sequence in the fragment had a $64 \%$ homology with the corresponding region of the Klebsiella aerogenes ure $C$ gene, one of the urease structural genes of the organism [25]. (The nucleotide sequence data reported in this paper will appear in the DDBJ, EMBL and GenBank nucleotide sequence databases with the accession number D86348.) This indicates that the expected part of the ure gene was cloned from $V$. parahaemolyticus.

\section{Distribution of the ure gene among $V$. parahaemolyticus strains}

The EcoRI-insert of pTI301 (601 bp in size) was labelled with digoxigenin to prepare a probe to detect the $V$. parahaemolyticus ure gene. The distribution of the ure gene in clinical and environmental $V$. parahaemolyticus isolates was investigated with this 


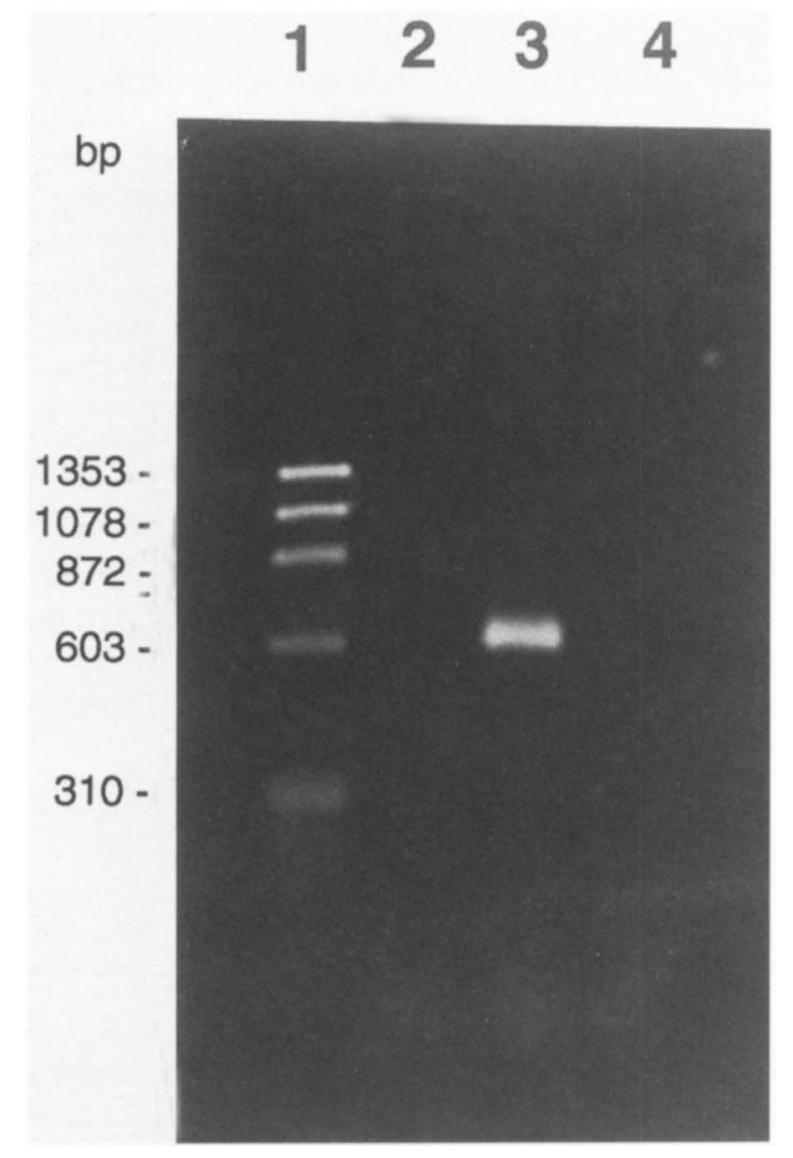

Fig. 1. PCR for the $V$. parahaemolyticus ure gene. Lane 1, molecular size markers $\phi \mathrm{X} 174 / \mathrm{Hae} \mathrm{III} ; 2$, E. coli HB101; 3, V. parahaemolyticus AQ4023 (urease-positive); 4, V. parahaemolyticus T4750 (urease-negative).

probe by colony hybridisation (Table 1). All the ureaseproducing strains hybridised with the ure probe, while the urease-negative strains did not. These results indicate that all the strains possessing the ure gene produce urease.

\section{Location of the ure and trh genes on chromosomal DNA of $V$. parahaemolyticus strains}

The trh gene in $V$. parahaemolyticus has been shown to exist exclusively on chromosomal but not on plasmid DNA [26, unpublished data]. The ure gene was also suggested, by Southern hybridisation, to exist exclusively on $V$. parahaemolyticus chromosome but not on plasmid DNA (data not shown). Consequently, the relative location of the ure and trh genes on $V$. parahaemolyticus chromosome was investigated. Representative strains from the trh type R1-R4 [24] were subjected to PFGE after treatment with a rare-cutting restriction endonuclease, Not I, to observe the macrorestriction patterns of chromosomal DNA. The patterns varied among the strains (Fig. 2a). However, the ure and trh probes both hybridised with the same Not I-fragment in each strain by Southern hybridisation (Fig. $2 b$ and c). These results suggest that, on the chromosomal DNA of the $V$. parahaemolyticus strains, the ure and trh genes localise within a relatively small portion.

\section{Discussion}

Detection of urease production is a simple biochemical assay, commonly used in the identification of bacteria. In the family Enterobacteriaceae, the genera Proteus, Klebsiella, Citrobacter, Yersinia and some species of Serratia and Enterobacter produce urease. The production of urease has served as a tool to differentiate many members of Enterobacteriaceae, vibrios and aeromonads. Like other vibrios, most $V$. parahaemolyticus strains do not produce urease, but some are known to do so. Since the first report of Huq et al. [10], ureasepositive clinical isolates of $V$. parahaemolyticus have been reported from various countries in the world, such as Singapore [14], the USA and Mexico [7, 12, 13, 16], Brazil [15], Malaysia [11], Thailand [17], Nigeria- [8] and Japan $[9,18]$. In many cases, the urease-positive $V$. parahaemolyticus strains form a minority in the population of clinical isolates, and TDH production is considered to be the most prevalent and important virulence marker of $V$. parahaemolyticus. However, in isolates from some areas, the urease-positive phenotype has been reported to be more closely associated with the pathogenicity of $V$. parahaemolyticus than TDH production $[7,8,12,13]$.

A recent study examined 489 clinical strains of $V$. parahaemolyticus isolated in Thailand, of which $8 \%$ of the strains were urease positive [17]. An interesting finding in the study was a perfect coincidence between urease-producing phenotype and the possession of the trh gene among V. parahaemolyticus strains [17]. This suggests that virulent (trh-possessing) V. parahaemo-

Table 1. Urease production and distribution of the ure gene in clinical and environmental $V$. parahaemolyticus strains

\begin{tabular}{lccc}
\hline Strain genotype & Number of strains & Urease production & Presence of ure* \\
\hline Clinical & 100 & - & - \\
$t d h^{+} t r h^{-}$ & 27 & + & + \\
$t d h^{+} t r h^{+}$ & 10 & + & + \\
$t d h^{-} t r h^{+}$ & 10 & - & - \\
$t d h^{-} t r h^{-}$ & 10 & - & - \\
Environmental & $t d h^{-} t r h^{-}$ & & \\
\hline
\end{tabular}

* The presence or the absence of the ure gene in the $V$. parahaemolyticus strains was determined by colony hybridisation. 
a

\section{$\begin{array}{llllllll}1 & 2 & 3 & 4 & 5 & 6 & 7 & 8\end{array}$}

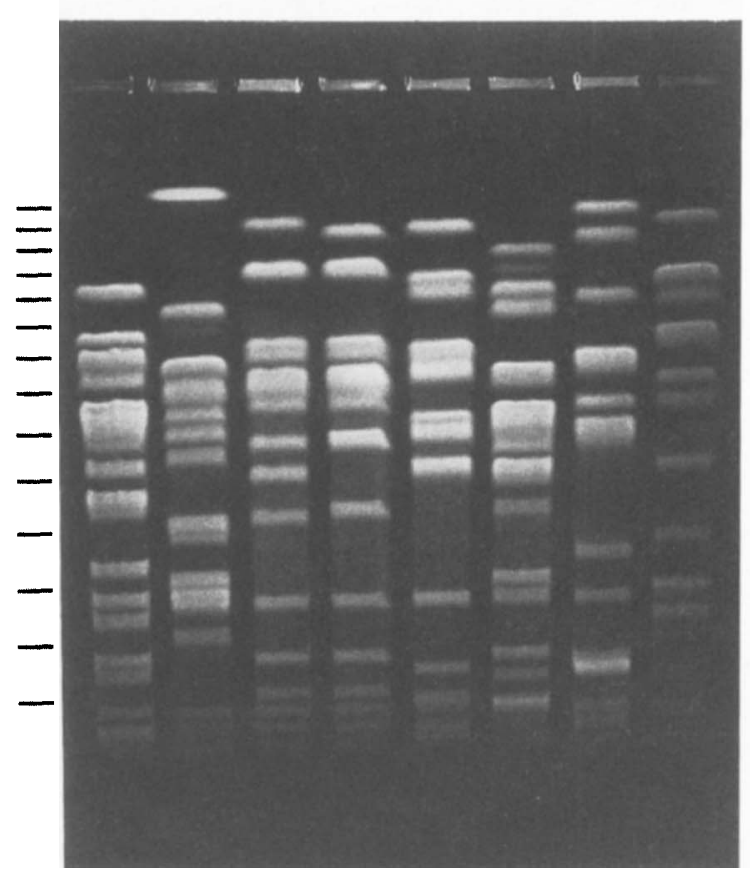

C

\section{$\begin{array}{llllllll}1 & 2 & 3 & 4 & 5 & 6 & 7 & 8\end{array}$}

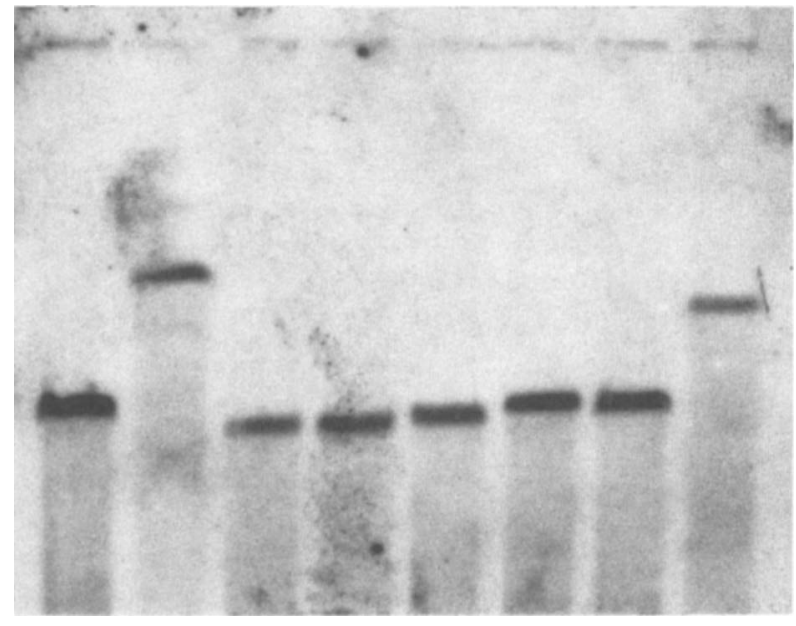

lyticus strains can be indicated by the urease-positive phenotype in clinical diagnosis [17]. At present, it is unknown if the finding is applicable to the clinical $V$. parahaemolyticus isolates from other areas. However, similar results were reported very recently from areas other than Thailand $[27,28]$.

In this study, a DNA probe was prepared to detect the V. parahaemolyticus ure gene. Colony hybridisation with the ure probe demonstrated that all the urepositive strains were urease-producers (Table 1). Considering the coincidence between the production of urease and the possession of trh in $V$. parahaemolyticus [17], it is concluded that the presence or the b
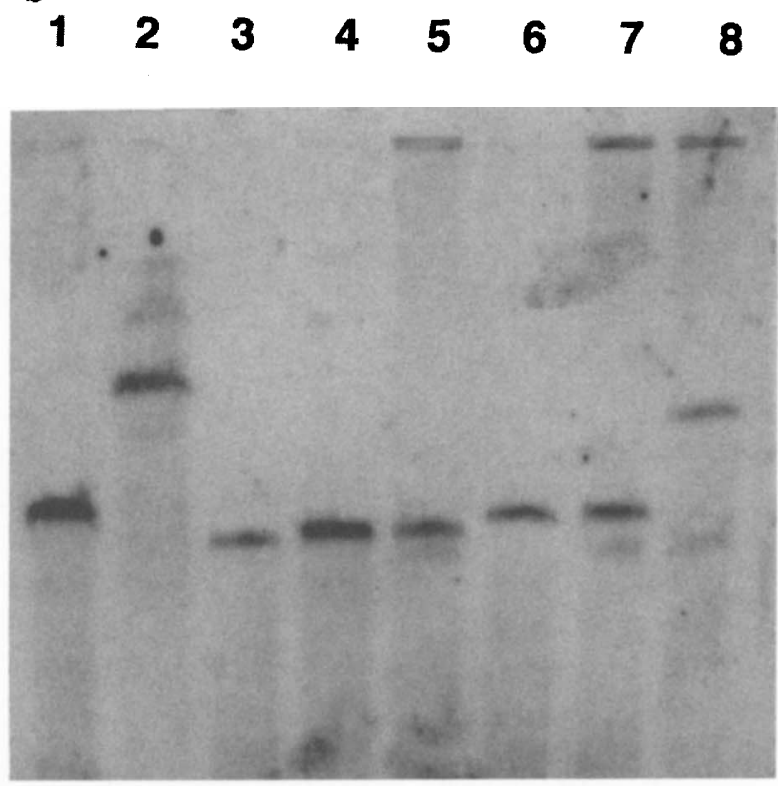

Fig. 2. PFGE of Not I-digested genomic DNA of $V$. parahaemolyticus strains and detection of ure and trh. $\mathbf{a}$, ethidium bromide staining; $\mathbf{b}$, hybridisation with the trh probe; c, hybridisation with the ure probe. PFGE was performed in $1 \times$ TBE buffer $(89 \mathrm{mM}$ Tris- $89 \mathrm{mM}$ boric acid- $2 \mathrm{mM}$ EDTA, $\mathrm{pH} 8.3$ ) with agarose $1 \%$ gel at $6 \mathrm{~V} / \mathrm{cm}$ for $24 \mathrm{~h}$ at $14^{\circ} \mathrm{C}$ with a ramp time of 6-60 s with clamped homogeneous field electrophoresis. Lane 1, strain VP81 with R1 trh; 2, VP389 (R1); 3, VP178 (R2); 4, VP453 (R2); 5, VP207 (R2); 6, VP343 (R3); 7, VP63 (R4); 8, VP466 (R4). Molecular size markers, lambda ladder (concatemers of $\lambda$ c1857 sam7) are noted at the left of panel a.

absence of the ure gene is completely coincident with that of the trh gene in $V$. parahaemolyticus strains. Furthermore, the relative location of ure and trh on $V$ parahaemolyticus chromosomal DNA was analysed by Southern hybridisation after PFGE. The results showed that, in all the strains examined, the ure and trh were detected on the same fragments in each strain after Not I-digestion of chromosomal DNA (Figs. 2b and $c$ ). This indicates that the ure and trh genes localise within a relatively close range on the chromosomal DNA of $V$. parahaemolyticus. These results, along with the results regarding distribution of the two genes, suggest that the ure and trh genes are genetically linked in $V$. parahaemolyticus strains. 
The present study provided a reason, at the molecular genetic level, why the urease-positive phenotype always associates with the possession of the trh gene. This information is important for clinical diagnosis. Instead of using other more specific, but more expensive, laborious assays such as the ELISA, DNA hybridisation or PCR, the possession of the trh gene will be known by urease activity, which is easy to assay.

The present findings also provide interesting information from an evolutionary point of view. It has been proposed that at some time in the past, $t d h$, and possibly $t r h$, were transferred from another organism into a small population of $V$. parahaemolyticus by plasmid-mediated and insertion sequence-mediated mechanisms [29-31]. As ure is genetically linked with trh in $V$. parahaemolyticus, as demonstrated in this study, the ure gene might also be somehow related to the ancient gene transfer event in $V$. parahaemolyticus. Although a close localisation of ure and trh on chromosomal DNA was found in this study, exact distances between the two genes have not been determined. More detailed positioning of the genes are now being investigated in this laboratory, together with the analysis of the flanking regions of ure and trh on chromosomal DNA.

Recently, a number of studies reported the relationship between bacterial pathogenicity and urease production [32-34]. Urease produced by Helicobacter pylori has been implicated in pathogenesis by virtue of its role in alkalinising the bacterium's micro-environment in the stomach and its toxicity to stomach epithelium [35]. In the case of the enteric pathogen, Yersinia enterocolitica, urease was shown to be responsible for acid resistance and to contribute to the virulence of the organism by enhancing the likelihood of bacterial survival during passage through the stomach [33]. In the case of $V$. parahaemolyticus, production of urease does not seem to be essential for the pathogenicity of $V$. parahaemolyticus, as most of the clinical isolates are urease-negative [17]. As the enterotoxicity of purified TRH has been demonstrated $[5,36]$, it is reasonable to consider that the pathogenicity of urease-positive strains, which, at the same time, have $t r h$, is primarily attributable to TRH. At present, we consider that the urease production by $V$. parahaemolyticus strains is merely a marker of trh possession. However, we cannot completely exclude the possibility that urease contributes to the pathogenicity of the organism by increasing its chances of survival during passage through the stomach, as has been previously demonstrated for $Y$. enterocolitica infection [33].

We thank Yuji Isegawa for helpful suggestions. This study was supported by a grant-in-aid for Scientific Research from the Ministry of Education, Science and Culture of Japan and the Japan Society for Promotion of Science.

\section{References}

1. Honda $\mathrm{T}$, lida $\mathrm{T}$. The pathogenicity of Vibrio parahaemolyticus and the role of the thermostable direct haemolysin and related haemolysin. Rev Med Microbiol 1993; 4: 106-113.

2. Sakazaki R, Tamura K, Kato T, Obara Y, Yamai S. Studies on the enteropathogenic, facultatively halophilic bacterium, Vibrio parahaemolyticus. III. Enteropathogenicity. Jpn J Med Sci Biol 1968; 21: 325-331.

3. Honda S-I, Goto I, Minematsu I et al. Gastroenteritis due to Kanagawa negative Vibrio parahaemolyticus. Lancet 1987; 1: $331-332$.

4. Honda T, Ni Y, Miwatani T. Purification and characterization of a hemolysin produced by a clinical isolate of Kanagawa phenomenon-negative Vibrio parahaemolyticus and related to the thermostable direct hemolysin. Infect Immun 1988; 56: $961-965$.

5. Honda T, Ni Y, Hata A et al. Properties of a hemolysin related to the thermostable direct hemolysin produced by a Kanagawa phenomenon negative, clinical isolate of Vibrio parahaemolyticus. Can J Microbiol 1990; 36: 395-399.

6. Shirai $\mathrm{H}$, Ito $\mathrm{H}$, Hirayama $\mathrm{T}$ et al. Molecular epidemiologic evidence for association of thermostable direct hemolysin (TDH) and TDH-related hemolysin of Vibrio parahaemolyticus with gastroenteritis. Infect Immun 1990; 58: 3568-3573.

7. Abbott SL, Powers C, Kaysner CA et al. Emergence of a restricted bioserovar of Vibrio parahaemolyticus as the predominant cause of Vibrio-associated gastroenteritis on the west coast of the United States and Mexico. J Clin Microbiol 1989; 27: 2891-2893.

8. Eko FO. Urease production in Vibrio parahaemolyticus: a potential marker for virulence. Eur $J$ Epidemiol 1992; 8: $627-628$.

9. Honda S, Matsumoto S, Miwatani T, Honda T. A survey of urease-positive Vibrio parahaemolyticus strains isolated from traveller's diarrhea, sea water and imported frozen sea foods. Eur J Epidemiol 1992; 8: 861-864.

10. Huq MI, Huber D, Kibryia G. Isolation of urease producing Vibrio parahaemolyticus strains from cases of gastroenteritis. Indian J Med Res 1979; 70: 549-553.

11. Jegathesan M, Paramasivam T. A strain of urease-producing Vibrio parahaemolyticus isolated in Malaysia. $J$ Diarrhoeal Dis Res 1985; 3: 162.

12. Kaysner CA, Aberta C, Trost PA et al. Urea hydrolysis can predict the potential pathogenicity of Vibrio parahaemolyticus strains isolated in the Pacific Northwest. Appl Environ Microbiol 1994; 60: 3020-3022.

13. Kelly MT, Stroh EMD. Urease-positive, Kanagawa-negative Vibrio parahaemolyticus from patients and the environment in the Pacific Northwest. J Clin Microbiol 1989; 27: 2820-2822.

14. Lam S, Yeo M. Urease-positive Vibrio parahaemolyticus strain. $J$ Clin Microbiol 1980; 12: 57-59.

15. Magalhaes M, Magalhaes V, Antas MG, Tateno S. Isolation of urease-positive Vibrio parahaemolyticus from diarrheal patients in northeast Brazil. Rev Inst Med Trop Sao Paulo 1991; 33: 263-265.

16. Oberhofer TR, Podgore JK. Urea-hydrolyzing Vibrio parahaemolyticus associated with acute gastroenteritis. J Clin Microbiol 1982; 16: 581-583.

17. Suthienkul $\mathrm{O}$, Ishibashi $\mathrm{M}$, Iida $\mathrm{T}$ et al. Urease production correlates with possession of the trh gene in Vibrio parahaemolyticus strains isolated in Thailand. $J$ Infect Dis 1995; 172: $1405-1408$

18. Suzuki N, Ueda Y, Mori H et al. [Serotypes of urease producing Vibrio parahaemolyticus and their relation to possession of $t d h$ and trh genes.] Kansenshogaku Zasshi 1994; 68: $1068-1074$.

19. Yamamoto K, Honda T, Miwatani T, Tamatsukuri S, Shibata S. Enzyme-labeled oligonucleotide probes for detection of the genes for thermostable direct hemolysin (TDH) and TDHrelated hemolysin (TRH) of Vibrio parahaemolyticus. Can $J$ Microbiol 1992; 32: 410-416.

20. Iida $T$, Yamamoto $K$. Cloning and expression of two genes encoding highly homologous hemolysins from a Kanagawa phenomenon-positive Vibrio parahaemolyticus T4750 strain. Gene 1990; 93: 9-15.

21. Sambrook J, Fritsch EF, Maniatis T. Molecular cloning: a laboratory manual, 2nd edn. Cold Spring Harbor, NY, Cold Spring Harbor Laboratory Press. 1989. 
22. Wilson K. Preparation of genomic DNA from bacteria. In: Ausubel FM, Brent R, Kingston RE et al. (eds) Current protocols in molecular biology, vol 1. New York, John Wiley and Sons. 1987: 2.4.1-2.4.2.

23. Smith CL, Cantor CR. Purification, specific fragmentation, and separation of large DNA molecules. Methods Enzymol 1987; 155: $449-467$.

24. Suthienkul O, Iida T, Park K-S et al. Restriction fragment length polymorphism of the $t d h$ and trh genes in clinical Vibrio parahaemolyticus strains. J Clin Microbiol 1996; 34: 1293-1295.

25. Mulrooney SB, Hausinger RP. Sequence of the Klebsiella aerogenes urease genes and evidence for accessory proteins facilitating nickel incorporation. $J$ Bacteriol 1990; 172: $5837-5843$.

26. Nishibuchi $M$, Taniguchi $T$, Misawa $T$, Khaeomanee-iam V, Honda T, Miwatani T. Cloning and nucleotide sequence of the gene $(t r h)$ encoding the hemolysin related to the thermostable direct hemolysin of Vibrio parahaemolyticus. Infect Immun 1989; 57: 2691--2697.

27. Osawa R, Okitsu T, Morozumi H, Yamai S. Occurrence of urease-positive Vibrio parahaemolyticus in Kanagawa, Japan, with specific reference to presence of thermostable direct hemolysin (TDH) and the TDH-related-hemolysin genes. Appl Environ Microbiol 1996; 62: 725-727.

28. Suzuki N, Ueda Y, Mori H et al. [Correlation between trh possession and urease production of clinical isolates of Vibrio parahaemolyticus.] Kansenshogaku Zasshi 1995; 69: $757-758$.
29. Nishibuchi M, Janda JM, Ezaki T. The thermostable direct hemolysin gene $(t d h)$ of Vibrio hollisae is dissimilar in prevalence to and phylogenetically distant from the $t d h$ genes of other vibrios: implications in the horizontal transfer of the tdh gene. Microbiol Immunol 1996; 40: 59-65.

30. Nishibuchi M, Kaper JB. Thermostable direct hemolysin gene of Vibrio parahaemolyticus: a virulence gene acquired by a marine bacterium. Infect Immun 1995; 63: 2093-2099.

31. Terai A, Baba K, Shirai H, Yoshida O, Takeda Y, Nishibuchi M. Evidence for insertion sequence-mediated spread of the thermostable direct hemolysin gene among Vibrio species. $J$ Bacteriol 1991; 173: 5036-5046.

32. Clemens DL, Lee B-Y, Horwitz MA. Purification, characterization, and genetic analysis of Mycobacterium tuberculosis urease, a potentially critical determinant of host-pathogen interaction. J Bacteriol 1995; 177: 5644-5652.

33. de Koning-Ward TF, Robins-Browne RM. Contribution of urease to acid tolerance in Yersinia enterocolitica. Infect Immun 1995; 63: 3790-3795.

34. Mobley HLT, Island MD, Hausinger RP. Molecular biology of microbial ureases. Microbiol Rev 1995; 59: 451-480.

35. Smoot DT, Mobley HLT, Chippendale GR, Lewison JF, Resau JH. Helicobacter pylori urease activity is toxic to human gastric epithelial cells. Infect Immun 1990; 58: 1992-1994.

36. $\mathrm{Xu} \mathrm{M}$, Yamamoto $\mathrm{K}$, Honda $\mathrm{T}$. Construction and characterization of an isogenic mutant of Vibrio parahaemolyticus having a deletion in the thermostable direct hemolysin-related hemolysin gene (trh). J Bacteriol 1994; 176: 4757-4760. 